\title{
The Analysis of Mathematics Adversity Quotient of Left Behind Junior High School Students in Rural Areas
}

\author{
Le Qin, Ying Zhou*, Wijaya Tommy Tanu \\ School of Mathematics and Statistics, Guangxi Normal University, Guilin, China \\ Email: ${ }^{* 799936971 @ q q . c o m ~}$
}

How to cite this paper: Qin, L., Zhou, Y. and Tanu, W.T. (2019) Paper Title. Open Journal of Social Sciences, 7, 331-342. https://doi.org/10.4236/jss.2019.710028

Received: August 15, 2019

Accepted: August 25, 2019

Published: October 25, 2019

Copyright $\odot 2019$ by author(s) and Scientific Research Publishing Inc. This work is licensed under the Creative Commons Attribution International License (CC BY 4.0).

http://creativecommons.org/licenses/by/4.0/

(c) (i) Open Access

\begin{abstract}
As a non-intellectual factor, Mathematics Adversity Quotient plays a crucial role in students' learning of mathematics. This study adopts the modified mathematics adversity quotient table measuring left-behind and non-left-behind students' Adversity Quotient in Chetian Minority Junior High School in Ziyuan, Guilin, Guangxi. It is found that the mathematics Adversity Quotient of non-left-behind junior high school students is generally higher than that of left-behind students, so there is a significant difference between them. Based on this situation, questionnaire survey and in-depth interview are adopted to explore the factors affecting the Adversity Quotient of left-behind junior high school students. Finally, it is concluded that home-school communication, teachers' and parents' care in school education have a significant influence on student's Mathematics Adversity Quotient.
\end{abstract}

\section{Keywords}

Mathematics Adversity Quotient, Left-Behind Junior High School Students, Non-Left-Behind Junior High School Students, Mathematics Education,

Home Education

\section{Introduction}

Adversity quotient (AQ) is one of the keys to successful mathematics learning. $\mathrm{AQ}$ is expected to be able to support students in achieving success when solving everyday problems [1]. AQ can also be considered as the biggest strength for someone to solve existing problems. The 6th census data stated that in 2010, there are more than 6100 million left-behind students in rural areas of China. About $30 \%$ of the rural children and half of the left-behind student are in com- 
pulsory education, the total is close to 30 million [2]. With this we can see that the children in compulsory education stage of the rural household are still staying behind. As a vulnerable group, the survival and development of rural left-behind children become a wide concern of the society. Now, left-behind junior high school students are generally afraid and tired of learning. This phenomenon is particularly evident in mathematics. In the long run, it will lead to its lack of ability to overcome mathematical learning difficulties. This ability is called mathematics adversity quotient (M-AQ).

\subsection{Core Concept Definition}

\subsubsection{Adversity Quotient}

Adversity Quotient was originated in the mid-1990s proposed by a famous American scholar and professional trainer Stoltz [3]. Adversity quotient is used to measure people's ability to withstand setbacks, get rid of adversity and surpass difficulties. The adversity quotient can be divided into four dimensions which are Control, Ownership, Reach and Endurance. These are referred to as CORE [4].

\subsubsection{Mathematics Adversity Quotient}

In 2002, Professor Zhang Dingqiang introduced the adversity quotient of mathematics education and defined its definition in an article called "Investigation and Analysis of Mathematics Adversity Quotient of Junior High School Students in Ethnic Areas" [5]. It mainly refers to the students' ability to cope with difficulties and setbacks in the process of learning mathematics. It includes four dimensions such as mathematical control (M-C), refers to the individuals' ability to control the adversity quotient in mathematics learning; mathematical ownership (M-O), refers to the individuals' ability to recognize the cause of adversity quotient in mathematics learning and the willingness to take responsibility and take the consequences; mathematical reach (M-R), refers to the individuals' ability to assess and perceive the scope of influence in mathematics learning; mathematical endurance (M-E) refers to the continuous time influence of adversity quotient on experiential learning [6].

This study investigates and analyses the current situation of mathematics adversity quotient of students in Chetian national junior high school, Guilin, Guangxi and also explores the factors affecting the mathematics adversity quotient of left-behind students. The aim is so that rural students can learn better and the teachers have a better teaching reference.

\section{Research Method}

\subsection{Population and Sample}

Taking into account the actual situation of the research object, a total of $350 \mathrm{ju}-$ nior high school students from Chetian National Junior High School were selected as the survey objects. The stratified and random sampling method is used 
to obtain samples. The stratified sampling is based on the year and distribution of the Chetian National Junior High School and random sampling according to the left-behind and non-left-behind students. Specific data can be seen in Table 1. Since the first part of this survey focuses on the comparison of mathematics quotients between left-behind and non-left-behind junior high school students, the selection of respondents ensures the same proportion of left-behind junior high schools. Secondly, this study involves junior high school students of different gender, grades and nationalities. Although it is comparable, but due to some geographical and research conditions, there will be some differences to the overall research. Therefore, the results obtain are only a certain degree of representation [7].

\subsection{Research Tools}

After taking into account all the actual situation of the subject under investigation, the investigation is divided into two parts. After the "Mathematics Adversity Quotient Scale" research done by Professor Zhang Dingqiang is complied, The revised questionnaire contains basic information such as the school's location, staying status, parental relationship, and teacher's level of interest, as well as mathematics control, ownership, reach, and endurance level test. The basic information of the student mainly selects the corresponding answer according to the actual situation, and the items of the four dimensions of the mathematical inverse quotation are scored by 1 - 5 points. The test items have a total of 250 indicators. Secondly, in order to make the scale more suitable for the surveyed subjects, this survey combines the opinions of 13 graduate students and 3 teachers to modify and delete inappropriate items. After revision, the test will be adopted to the left-behind students of Chetian National Junior High School, Guilin, Guangxi. Firstly we will investigate and analyse the adversity quotient between left-behind and non-left-behind students in the area. The scale will be from 1-5 where the higher the score, the higher their adversity quotient. After seeing the survey result, questionnaires and in-depth interviews are done to know the factors affecting the mathematics adversity quotient of left-behind junior high school students. The questionnaires and interviews mainly focuses on the level of parental care, parents expectation as well as frequency level of communication in a school-level homeschooling and teacher care degree.

Table 1. Basic information of sample students.

\begin{tabular}{|c|c|c|c|c|c|c|c|c|c|}
\hline \multirow[b]{2}{*}{ Category } & \multicolumn{2}{|c|}{ Students Situation } & \multicolumn{2}{|c|}{ Gender } & \multicolumn{3}{|c|}{ Grade } & \multicolumn{2}{|c|}{ Ethnic Group } \\
\hline & $\begin{array}{c}\text { Left-Behind } \\
\text { Junior High } \\
\text { School } \\
\text { Student }\end{array}$ & $\begin{array}{l}\text { Non-Left- } \\
\text { Behind Junior } \\
\text { High School } \\
\text { Student }\end{array}$ & Male & Female & $\begin{array}{c}\text { 7th } \\
\text { Grade }\end{array}$ & $\begin{array}{c}\text { 8th } \\
\text { Grade }\end{array}$ & $\begin{array}{c}\text { 9th } \\
\text { Grade }\end{array}$ & $\begin{array}{l}\text { Han } \\
\text { Tribe }\end{array}$ & $\begin{array}{c}\text { Minority } \\
\text { Ethnic } \\
\text { Group }\end{array}$ \\
\hline $\begin{array}{l}\text { Number } \\
\text { of People }\end{array}$ & 175 & 175 & 168 & 182 & 115 & 125 & 110 & 228 & 122 \\
\hline
\end{tabular}




\subsection{Data Collection and Processing}

The questionnaire is conducted for the students from Chetian National Junior High School, Guilin, Guangxi. Guidance for the students was conducted before the test and follow-up interviews were conducted on the problems that arise. There were a total of 350 questionnaires distributed and only 296 of them were valid of which 96, 107, 93 are valid for 7th grade, 8th grade and 9th grade respectively.

The study uses Microsoft Excel and Spss 24.0 for data processing. It mainly uses independent $\mathrm{t}$-test sampling and variance analysis. In terms reliability, the Cronbach's alpha coefficient is 0.891 . For mathematical control, ownership, reach, and endurance, their Cronbach's alpha coefficient is $0.922,0.954,0.913$, 0.806 respectively (Table 2 ).

The KMO value of the factor analysis scale is 0.886 . This indicates that it is a suitable factor analysis (Table 3). In the principal component analysis, the cumulative total variance of the four factors has reached $73.581 \%$. This means that the four factors reflect the main aspects of the mathematics adversity quotient for junior high school students. We can also see from the post-rotation component matrix that the four dimensions are internal consistence. In summary we can see that the questionnaire has a high reliability and validity.

According to Hendriana \& Sumarmo [8], mathematical dispositions are attitudes that show: 1) confidence; 2) flexible; 3 ) persistent, tenacious performing mathematical tasks; 4) interest, curiosity; 5) monitor, reflect on their own appearance and reasoning; 6) passion in learning mathematics; 7) implements mathematics to other situations; 8) appreciate the role of mathematics; 9) rape and metacognition; 10) share with others. Polking [9] argues that mathematical dispositions show: 1) confidence in using mathematics, solving problems; 2) flexibility in investigating mathematical ideas and seeking alternative methods of problem solving; 3) diligently doing math tasks; 4) interest, curiosity in mathematics; 5) tend to monitor; 6) assessing mathematical applications to other situations; 7) appreciation (appreciation).

Table 2. Reliability statistic scale.

\begin{tabular}{ccc}
\hline & Cronbach's Alpha & N of Items \\
\hline Reliability & 0.891 & 20 \\
Mathematical Control & 0.922 & 5 \\
Mathematical Ownership & 0.954 & 5 \\
Mathematical Reach & 0.913 & 5 \\
Mathematical Endurance & 0.806 & 5
\end{tabular}

Table 3. KMO and Bartlett test.

\begin{tabular}{ccc}
\hline \multicolumn{2}{c}{ KMO sampling homogeneity } & 0.886 \\
\hline & Chi-Square Distribution & 4541.567 \\
Bartlett sphericity test & Degree of Freedom & 190 \\
& Significant & 0.000
\end{tabular}




\section{Results and Discussion}

\subsection{Analysis of Research Status}

\subsubsection{The Status Quo of Mathematics Adversity Quotient for Left-Behind and Non-Left-Behind Junior High School Students}

The survey concluded that the mathematics adversity quotient of left-behind and non-left-behind junior high school students is 58.58 and 63.82. The non-left-behind student has a high adversity quotient compared to left-behind junior high school students (see Table 4). The left-behind students have a higher mathematical endurance while they have a lower mathematical ownership. On the other hand, the mathematical control of non-left-behind student was the best but their mathematical rule control is relatively poor. From the average score of the mathematics adversity quotient, we can see that the mathematics adversity quotient for left-behind and non-left-behind students is generally low. The score of the students' adversity quotient were barely a pass as the total score of the questionnaire were 100 points. This shows that there is still a need for improvement in the overall mathematics adversity quotient for junior high school students. There is a significant difference in the variance analysis of the mathematics adversity quotient between left-behind and non-left-behind student ( $\mathrm{F}=$ 11.529, $\mathrm{p}=0.01<0.05$ ) (see Table 5). Through the follow-up interview done, we found out that most of the guardians of left-behind students are every other generation (grandparents). Due to their age and cultural standard, most of them have little to no knowledge about their children's mathematics and psychological counselling skills. So, when left-behind students encounter setbacks in the learning process of mathematics, guardians were unable to guide them. Therefore, the problems faced by left-behind students can't be resolved immediately. In the long run, there will be fears, loss of confidence and dislike to study which will affect the students' mathematics adversity quotient. On the other hand, the parents of non-left-behind student have a relatively rich knowledge, skills and energy on how to manage their children's mathematical learning and other issues. When children encounter difficulties in learning mathematics, parents are able to make time to guide their children. After seeing both sides of the situation, we now understand why there is a significant difference in adversity quotient of left-behind and non-left-behind student.

Table 4. Comparison of mathematics adversity quotient of left-behind and non-left-behind junior high school students.

\begin{tabular}{|c|c|c|c|c|c|c|}
\hline Category & $\begin{array}{c}\text { Mathematics } \\
\text { Adversity } \\
\text { Quotient }\end{array}$ & $\begin{array}{c}\text { Mathematic } \\
\text { Control }\end{array}$ & $\begin{array}{l}\text { Mathematica } \\
\text { Ownership }\end{array}$ & $\begin{array}{c}\text { Mathemati } \\
\text { Reach }\end{array}$ & $\begin{array}{l}\text { Mathematical } \\
\text { Endurance }\end{array}$ & Comparison \\
\hline $\begin{array}{l}\text { Left-behind } \\
\text { student }\end{array}$ & 58.58 & 14.76 & 13.10 & 13.88 & 16.83 & $4>1>3>2$ \\
\hline $\begin{array}{c}\text { Non-left- } \\
\text { behind student }\end{array}$ & 63.84 & 15.30 & 15.82 & 15.45 & 17.27 & $4>2>3>1$ \\
\hline
\end{tabular}


Table 5. Analysis of mathematics adversity quotient variance for left-behind and non-left-behind students.

\begin{tabular}{cccccc}
\hline \multicolumn{6}{c}{ Mathematics adversity quotient } \\
\hline & Sum of square & df & Mean square & F & Significant \\
\hline Between the group & 2048.175 & 1 & 2048.175 & 11.549 & 0.001 \\
Inside the group & $52,138.686$ & 294 & 177.342 & & \\
Total & $54,186.861$ & 295 & & & \\
\hline
\end{tabular}

\subsubsection{The Status Quo of Mathematics Adversity Quotient on Different Genders of Left-Behind and Non-Left-Behind Junior High School Students}

The survey concluded that the mathematics adversity quotient of left-behind male/female student and non-left-behind male/female students are $62.48 / 55.53 / 68.73 / 57.80$. With this we can see that the mathematics adversity quotient of male students is generally higher than female students. The analysis on the variance of gender for mathematics adversity quotient on left-behind and non-left-behind students is shown in Table 6. There is a significant difference in their adversity quotient between the male and female junior high school students $(\mathrm{F}=2.638, \mathrm{p}=0.001<0.05 ; \mathrm{F}=8.679, \mathrm{p}=0.000<0.05)$. Although some of the girls have a higher adversity quotient score and mathematics score, but we have found that there are influences from the environment and psychology when girls are studying mathematics. Considering natural weaknesses, male students are worse in the thinking and perseverance aspect of studying mathematics. In terms of interest, girls tend to have more interest in studying language. Therefore, it is necessary for teachers' to attract the students' attention and take up measures to improve the female students' mathematics adversity quotient.

\subsubsection{Mathematics Adversity Quotient on Different Gender of Left-Behind and Non-Left-Behind Junior High School Students} According to the survey, the mathematics adversity of left-behind and non-left-behind student in the minority school is $51.55,58.38,71.25 / 50.62$, $62.90,72.09$. Comparison in the grades of mathematics adversity quotient in minority areas is shown in Table 7. It is found that there is a significant difference in the mathematics adversity quotient between 7 th, 8 th and 9th grade $(F=$ $35.87, \mathrm{p}=0.000<0.05)$. There is also a significant difference in the mathematics adversity quotient between the three grades of left-behind and non-left-behind junior high school students $(\mathrm{F}=45.128, \mathrm{p}=0.000<0.05)$. From the interview, it is found that the schools surveyed are junior high schools in rural areas. So the basics of the students are generally poor especially for the students who have just graduated from primary school to junior high school and adaptation takes a while. As the students' grade increase, students will have new learning habits, methods and improvements in adaptability, confidence, ability and other aspects. That is why teachers should let the students adapt to the mathematics learning method and model of junior high school as soon as possible as this will improve the students' adversity quotient. 
Table 6. Comparison of gender on the mathematics adversity quotient on left-behind and non-left-behind junior high school students.

\begin{tabular}{cccccc}
\hline Student Situation & Gender & Equalisation & Standard Deviation & F Value & Significant (P) \\
\hline Left-Behind & Male & 62.48 & 12.974 & 2.638 & 0.001 \\
Student & Female & 55.53 & 11.634 & & \\
Non-Left-Behind & Male & 68.73 & 11.695 & & \\
Student & Female & 57.80 & 14.261 & & 0.000 \\
\hline
\end{tabular}

Table 7. Comparison of the class grade on the mathematics adversity quotient of left-behind and non-left-behind junior high school students.

\begin{tabular}{cccccc}
\hline Student Situation & Class & Equalisation & Standard Deviation & F Value & Significant (P) \\
\hline \multirow{2}{*}{ Left-Behind } & 9th grade & 71.25 & 12.152 & & \\
Student & 8th grade & 58.38 & 10.474 & 35.873 & 0.000 \\
& 7th grade & 51.55 & 9.464 & & \\
Non-Left-Behind & 9th grade & 72.09 & 9.429 & & \\
Student & 8th grade & 62.90 & 12.275 & 45.128 & 0.000 \\
& 7th grade & 50.62 & 11.866 & & \\
\hline
\end{tabular}

\subsubsection{Mathematics Adversity Quotient on Different Ethnic Group of} Left-Behind and Non-Left-Behind Junior High School Students

According to the survey, the mathematics adversity quotient of the Han and minority ethnic group of the left-behind student that lives in the minority areas are 59.69 and 58.05. While the mathematics adversity of the Han and minority ethnic group of the non-left-behind student are 62.46 and 64.39. The comparison of the students' ethnic group with the mathematics adversity quotient in minority areas is shown in Table 8. It is found that there is no significant difference in the mathematics adversity quotient between Han and minority ethnic group students $(\mathrm{F}=0.007, \mathrm{p}=0.456>0.05)$. There is also no significant difference in the mathematics adversity quotient of non-left-behind junior high school students that comes from Han tribe and minority ethnic group $(\mathrm{F}=0.387, \mathrm{p}=$ $0.457>0.05)$. This indicates that junior high school students of different ethnic group have the same ability to fight defeat. The subjects surveyed were all enrolled in the same school, learning environment, living standards and teachers' teaching ability. Therefore, there is no significant difference in the mathematics adversity quotient between junior high school students who comes from the Han tribe and minority ethnic group.

\subsection{Influencing Factors}

\subsubsection{Family's Influence on the Mathematics Adversity Quotient of Left-Behind Junior High School Student in the Rural Area \\ The influence of parental concern on the mathematics adversity quotient of left-behind junior high school student in the rural area}

We believe that parents' concern is one of the factors affecting the students' mathematics adversity quotient. The survey concluded that the students' average adversity quotient score of parents who often, occasionally, sometimes and never 
cares are $62.21,61.66,53.81,52.65$ respectively (Table 9). There is a significant difference $(\mathrm{F}=5.870, \mathrm{p}=0.001<0.05)$, which indicates that the parents who care more of their children, their mathematics adversity quotient are higher. This means that parents should start caring for their children so that they will be able to learn and live healthily.

The influence of parents' expectation on the mathematics adversity quotient of left-behind junior high school student in the rural area

According to the survey, the parents of the left-behind student have different expectations for their children's academic qualifications. Students' mathematics adversity quotient with an academic qualification of junior high school, high school, university and post-graduate and above has a mathematics adversity quotient of 59.19, 56.74, 57.74 and 63.53 respectively (Table 10). There is no obvious law and also there is not significant difference $(\mathrm{F}=1.291, \mathrm{p}=0.280<$ 0.05). This indicates that parents' expectations have no significant difference in the mathematics adversity quotient of left-behind junior high school student in the rural area.

Table 8. Comparison of the ethnic group on the mathematics adversity quotient of left-behind and non-left-behind junior high school students.

\begin{tabular}{cccccc}
\hline $\begin{array}{c}\text { Student } \\
\text { Situation }\end{array}$ & $\begin{array}{c}\text { Ethnic } \\
\text { Group }\end{array}$ & Equalisation & $\begin{array}{c}\text { Standard } \\
\text { Deviation }\end{array}$ & F Value & Significant (P) \\
\hline $\begin{array}{c}\text { Left-Behind } \\
\text { Student }\end{array}$ & Han Tribe & 59.69 & 12.658 & 0.007 & 0.456 \\
Mon-Left- & Han Tribe & 58.05 & 12.714 & & 0.457 \\
Behind Student & Minority Ethnic Group & 64.39 & 14.387 & 0.387 & \\
\hline
\end{tabular}

Table 9. The influence of parental concern on the mathematics adversity quotient of left-behind junior high school student in the rural area.

\begin{tabular}{cccccc}
\hline $\begin{array}{c}\text { Student } \\
\text { Situation }\end{array}$ & Parental & Equalisation & $\begin{array}{c}\text { Standard } \\
\text { Deviation }\end{array}$ & F Value & Significant (P) \\
\hline \multirow{3}{*}{$\begin{array}{c}\text { Concern } \\
\text { Student }\end{array}$} & Often Cares & 62.21 & 13.264 & 5.870 & 0.001 \\
& Sometimes Cares & 61.66 & 12.282 & & \\
& Rarely Cares & 53.81 & 10.617 & & \\
& Never Cares & 52.65 & 12.644 & \\
\hline
\end{tabular}

Table 10. The influence of parents' expectation on the mathematics adversity quotient of left-behind junior high school student in the rural area.

\begin{tabular}{|c|c|c|c|c|c|}
\hline $\begin{array}{l}\text { Student } \\
\text { Situation }\end{array}$ & $\begin{array}{c}\text { Parents' } \\
\text { Expectation }\end{array}$ & Equalisation & $\begin{array}{l}\text { Standard } \\
\text { Deviation }\end{array}$ & F Value & Significant $(\mathrm{P})$ \\
\hline \multirow{4}{*}{$\begin{array}{l}\text { Left-Behind } \\
\text { Student }\end{array}$} & $\begin{array}{c}\text { Junior High School } \\
\text { Graduate }\end{array}$ & 59.19 & 11.864 & 1.291 & 0.280 \\
\hline & High School Graduate & 56.74 & 13.785 & & \\
\hline & University Graduate & 57.74 & 10.939 & & \\
\hline & $\begin{array}{c}\text { Master Graduate and } \\
\text { Above }\end{array}$ & 63.53 & 15.113 & & \\
\hline
\end{tabular}




\subsubsection{Schools' Influence on the Mathematics Adversity Quotient of Left-Behind Junior High School Student in the Rural Area}

The influence of home-school communication frequency on the mathematics adversity quotient of left-behind junior high school student in the rural area

According to the survey, the students' mathematics adversity quotient who frequently, sometimes, occasionally, never communicate between home and school have a mathematics adversity quotient of $64.92,59.07,57.59$, and 54.47 respectively (Table 11$)$. There is a significant difference $(\mathrm{F}=3.693, \mathrm{p}=0.013<$ 0.05). This indicates that communication frequency has a significant impact on the students' mathematics adversity quotient. After primary school, students tend to go to boarding schools where they live in school. Parents often need to ask the school to know the learning situation of their children. In order to let the students' learn better, parents need to also care about the students' situation. Schools and parents both need to take the initiative to know the students' mathematics learning and personal life from each other.

The influence of teachers' concern on the mathematics adversity quotient of left-behind junior high school student in the rural area

The survey concluded that the students' average adversity quotient score of teachers who often, occasionally, sometimes and never care are 67.61, 59.77, 54.32 , and 44.91 respectively (Table 12 ). There is a significant difference ( $\mathrm{F}=$ $44.952, \mathrm{p}=0.000<0.05)$, which indicates that teachers' care is one of the factors that can affect the students' mathematics adversity quotient. Teachers have the most direct and deepest understanding of the students which is a key point. So, teachers should improve their sense of responsibility and pay more attention to students in order to improve the students' mathematics adversity quotient.

Table 11. The influence of home-school communication frequency on the mathematics adversity quotient of left-behind junior high school student in the rural area.

\begin{tabular}{cccccc}
\hline $\begin{array}{c}\text { Student } \\
\text { Situation }\end{array}$ & $\begin{array}{c}\text { School Communication } \\
\text { Frequency }\end{array}$ & Equalisation & $\begin{array}{c}\text { Standard } \\
\text { Deviation }\end{array}$ & F Value & $\begin{array}{c}\text { Significant } \\
(\mathrm{P})\end{array}$ \\
\hline & Frequently Communicate & 64.92 & 11.262 & 3.693 & 0.013 \\
$\begin{array}{c}\text { Left-Behind } \\
\text { Student }\end{array}$ & Sometimes Communicate & 59.07 & 12.794 & & \\
& Occasionally Communicate & 57.59 & 11.919 & \\
& Never Communicate & 54.47 & 12.693 & \\
\hline
\end{tabular}

Table 12. The influence of teachers' concern on the mathematics adversity quotient of left-behind junior high school student in the rural area.

\begin{tabular}{cccccc}
\hline $\begin{array}{c}\text { Student } \\
\text { Situation }\end{array}$ & Teachers' Concern & Equalisation & $\begin{array}{c}\text { Standard } \\
\text { Deviation }\end{array}$ & F Value & Significant (P) \\
\hline \multirow{2}{*}{$\begin{array}{c}\text { Left-Behind } \\
\text { Student }\end{array}$} & Often Cares & 67.61 & 11.249 & 44.952 & 0.000 \\
& Sometimes Cares & 59.77 & 7.670 & & \\
& Rarely Cares & 54.32 & 8.022 & & \\
& Never Cares & 44.91 & 7.266 & \\
\hline
\end{tabular}




\section{Conclusions}

Based on the results, mathematics adversity quotient of non-left-behind students is significantly higher than that of left-behind junior high school students. The mathematical ownership of left-behind students is generally low which indicates that they find it difficult to learn mathematics when encountering setbacks or problems. In another test, it shows that there is a significant difference in the mathematics adversity quotient when comparing gender and class grades but there is no significant difference when comparing different ethnic groups [10].

As there is a significant difference in the mathematics adversity quotient between left-behind and non-left-behind junior high school students, there are factors that affect the low adversity quotient of left-behind students. The research mainly focuses on the junior high school in rural areas and it will mainly concentrate on the family and school aspect.

\section{Suggestions}

Because the degree of parents' concern has a profound impact on the students' mathematics adversity quotient, therefore family education should be the centre. Even when parents' go out to work for a longer time, they should still keep in touch and communicate with their children and teachers, paying attention to their children's mental journey when learning mathematics in order to build a basis for adversity quotient. Educator Li Hao said that "hardship" is like an indispensable spiritual nutrition for the growth of children. That is why when a child encounters a mathematical dilemma rather than blaming them, we should encourage the child to face the problem with a positive attitude and guide the child to take effective measures to get out of the problem. Also, don't just focus in the child's mathematics score but rather pay more attention to the learning process. Affirmation, appropriate praise and incentives are an effective way to guide the children and improve their mathematics adversity quotient [11].

As a part of qualified education, a mental health education should be included in the teaching of various subjects. However, under the guidance of junior high school entrance examination, only a few people pay attention to the students' mental health. That is why it is important for a mathematics teacher to be the core position to train adversity quotient by using class time effectively to teach mental health education. For most junior high school student in the rural area finds mathematics to be a hard subject. Their teachers should say more attending to the left-behind students in which they have a low adversity quotient [12]. When students encounter a hard mathematics question, teachers should give them guidance by using small group discussions, face-to-face help, etc. Teachers should give them the correct guidance so that they would be able to solve the problem. Also, mathematics teachers should discuss children's mathematics learning process with their parents. Like as Sukhomlynsky said that "Teaching effectiveness depends on the learning impact in school and at home". Being a mathematics teacher, they are the first ones to know the material and learning 
situation. That is why it would be better for them to communicate with children's parents to be able to know the basic situation from their community and ask parents' feedback when children's are learning mathematics. This way is an effective way to solve the communication problem between school and family as this can serve as a bridge between the teachers and parents. This way we can work together to increase the students' mathematics adversity quotient.

\section{Acknowledgements}

We would like to thank to Guangxi Normal University for the research fund which has been given to the researcher. This paper is based from Guangxi in 2016 "A study on the mode of joint training of Postgraduates-Taking the direction of mathematics course and teaching theory as an example" (JGY2016003) and Guangxi Zhuang Autonomous Region Postgraduate Education Innovation Project "Attribution Analysis of Mathematical Inverse Quotient of Junior Middle School Students in Minority Areas Based on NVIVO Coding" (XYCSZ2019084).

\section{Conflicts of Interest}

There is no conflict of internet regarding the publication of this paper.

\section{References}

[1] Hidayat, W. and Prabawanto, S. (2018) Improving Students' Creative Mathematical Reasoning Ability Students through Adversity Quotient and Argument Driven Inquiry Learning. Journal of Physics. Conference Series, 948, Article ID: 012005. https://doi.org/10.1088/1742-6596/948/1/012005

[2] Duan, C.C., Lu, L.D., Guo, J. and Wang, Z.P. (2013) The Basic Situation of the Survival and Development of Left-Behind Children in Rural Areas in China-Based on the Analysis of the Sixth Census Data. Population Journal, 3, 37-49.

[3] Stoltz, P.G. (2004) Adversity Quotient: Mengubah Hambatan Menjadi Peluang Edisi Kelima. Grasindo, Jakarta.

[4] Zhang, Y. and Wu, X. (2019) A Survey of Mathematical Inverse Quotient Levels of High School Students in Weinan Shui Area. Journal of Mathematics Education, 28, 88-93.

[5] Cao, C.Y. and Zhang, D.Q. (2015) Ding Hai's Rematch. Investigation and Analysis of Mathematical Negative Quotient of Junior Middle School Students in Ethnic Areas-A Case Study of Mathematical Negative Quotient of Tibetan and Chinese Junior Middle School Students in Gannan Tibetan Autonomous Prefecture. Journal of Mathematics Education, 24, 50-53.

[6] Cao, C.Y. and Zhang, D.Q. (2012) Investigation and Analysis of Mathematics Inverse Quotient of Junior Middle School Students-Based on Mathematical Examination Results and Mathematical Examination Anxiety Dimensions. Journal of Mathematics Education, 21, 23-25.

[7] Wang, F. (2017) Investigation and Analysis of Mathematics Inversion and Mathematics Anxiety of Junior High School Students. Qinghai Normal University, Xining.

[8] Hendriana, H. and Soemarmo, U. (2014) Penilaian pembelajaran matematika. Refika Aditama, Bandung. 
[9] Herlina, S., Turmudi and Dahlan, J.A. (2012) Efektivit as Strategi React Dalam Upaya Peningkatan Kemampuan Komunikasi Matematis Siswa Sekolah Menengah Pertama. Journal of Teaching MIPA, 17, 1-7.

[10] Stoltz, P.G. (1997) Adversity Quotient: Turning Obstacles into Opportunities.

[11] Francis, D. (2000) Adversity Quotient: Turning Obstacles into Opportunities: P.G. Stoltz; John Wiley and Sons, New York. Technovation, 20, 402. https://doi.org/10.1016/S0166-4972(00)00010-9

[12] Xu, F.F., Shan, Q.F., Hong, B.Q., et al. (2015) Research on the Relationship between Teenage Adversity and Parenting Style. Chinese Journal of School Health, 36, 1665-1668. 